\title{
Synthesis, Characterization, Free Radical Scavenging and Cytotoxic Activities of Phenylvilangin, a Substituted Dimer of Embelin
}

\begin{abstract}
K. NARENDRAN, JAYALAKSHMI S ${ }^{1}$, NIVEDHITHA MS ${ }^{1}$, A. SARVANAN, AMIRTHA GANESAN S² AND E. SUKUMAR ${ }^{3 *}$
Department of Chemistry, Saveetha Engineering College, Thandalam, Chennai 602 105, ${ }^{1}$ Department of Conservative Dentistry and Endodontics, Saveetha Dental College and Hospitals, Saveetha Institute of Medical and Technical Sciences (Deemed University), Chennai-600 077, '2Department of Chemistry, Saveetha School of Engineering, Saveetha Institute of Medical and Technical Sciences (Deemed University), Thandalam Campus, Chennai 602 105, ${ }^{3}$ Department of Research and Development, Saveetha Institute of Medical and Technical Sciences, (Deemed University), Thandalam Campus, Chennai 602 105, India
\end{abstract}

\section{Narendra et al.: Phenylvilangin-Synthesis and Biological activities}

\begin{abstract}
Plants contain a wide variety of secondary metabolites that are used either as drugs or lead compounds in the synthesis of interesting chemicals that show promise in drug discovery. Quinones and their derivatives are one such group of specialized compounds that exhibit amazing biological properties. In this study, a benzoquinone derivative phenylvilangin has been synthesized from the naturally occurring embelin and its structure was confirmed by Infrared Spectroscopy, Proton Nuclear Magnetic Resonance, Carbon-13 nuclear magnetic resonance, Distortionless enhancement by polarization transfer and mass spectral analysis. Phenylvilangin has been screened for free radical scavenging and cytotoxic by in vitro methods wherein it exhibited significant activities suggesting that it could be a compatible material for further investigation to develop as a potential drug candidate. On comparison of the above bifunctional activities of phenylvilangin with those of the parent quinone embelin and another derivative vilangin, it has been found that phenylvilangin possessed better potential than the other two compounds.
\end{abstract}

Key words: Phenylvilangin, synthesis, characterization, free radical scavenging and cytotoxic activities

Embelin (compound 2), a naturally occurring benzoquinone, has been reported to possess a plethora of biological activities ${ }^{[1]}$. Vilangin (compound 3), the dimer of compound 2, has earlier been studied for antimicrobial, antioxidant and anticancer properties ${ }^{[2]}$. In this report, the synthesis and characterization of phenylvilangin (compound 1) by spectroscopic data (Infrared Resonance ( ${ }^{1} \mathrm{HNMR}$ ), Carbon-13 nuclear magnetic Spectroscopy (IR), Proton Nuclear Magnetic resonance $\left({ }^{13} \mathrm{CNMR}\right)$, Distortionless enhancement by polarization transfer (DEPT) and Mass Spectroscopy (MS)) are presented in addition to its free radical scavenging and cytotoxic activities. The activities of compound 1 have also been compared with those of compound 2 and compound 3. Compound 2 has been isolated from the berries of Embelia ribes Burm.f. (Family: Primulaceae) $)^{[3]}$ and compound 3 was synthesized from compound 2 as per the reported procedures $^{[2]}$. Compound 1 has been prepared by

*Address for correspondence

E-mail: drsuku3@gmail.com

September-October 2020 the following procedure. A mixture of $2(3 \mathrm{~g})$ and benzaldehyde solution $(0.5 \mathrm{~g})$ were taken in $100 \mathrm{ml}$ of acetic acid in a round-bottom flask. With vigorous stirring, the reaction temperature was maintained at $40-45^{\circ}$ in a water bath. After $10 \mathrm{~min}$, the reaction mixture was allowed to cool wherein a bright orange compound 1 precipitated. It was filtered and crystallized from acetone (melting point: $258-260^{\circ}$ ). The purity of the final product was assessed by Thin Layer Chromatography (TLC). The structure has been confirmed by spectral data. IR: $v_{\max } \mathrm{KBr}\left(\mathrm{cm}^{-1}\right)$ : 3416 (hydroxyl), 3153 (=C-H stretch; aromatic), 2925 (bridged -C-H stretch), 2854 (-C-H stretch; alkyl), 1623 (quinine carbonyl),

This is an open access article distributed under the terms of the Creative Commons Attribution-NonCommercial-ShareAlike 3.0 License, which allows others to remix, tweak, and build upon the work non-commercially, as long as the author is credited and the new creations are licensed under the identical terms

Accepted 14 December 2020

Revised 04 December 2020

Received 11 April 2020

Indian J Pharm Sci 2020;82(5):909-912 
1400, 1344, 1320, 1124, 750 (rocking methylene), 697 (methylene bending). ${ }^{1} \mathrm{HNMR}\left(600 \mathrm{MHz}, \mathrm{CDCl}_{3}\right.$, ppm): $\delta 7.28(5 \mathrm{H}, \mathrm{m}$, aromatic protons $), 5.69(1 \mathrm{H}, \mathrm{s}$, bridged $\mathrm{H}-\mathrm{a}), 2.42(4 \mathrm{H}, \mathrm{t}), 1.46(4 \mathrm{H}, \mathrm{m}, \mathrm{H}-\mathrm{c}), 1.29$ (34.87H, t, H-b), 0.88 (6H, t, H-d) (fig. 1). ${ }^{13} \mathrm{CNMR}$ (150 MHZ, CDCl3 , ppm): $\delta 170.7$ (C-1,C-4,C-1',C-4'), 138.2(C-3, C-3'), 133.8 (C-6, C-6'), 130.3(C-19), 128.6 (C-2,C-2'), 128.5(C-20, C-24), 126.9(C-21, C-23), 116.7(C-22), 113.9(C-5, C-5'), 36.6(C-18), 32.0(C15, C-15'), 29.7(C-9,C-10,C-9',C-10'), 29.6(C-11, C-12, C-13, C-11', C-12', C-13'), 29.4 (C-14,C-14'), 28.0(C-8,C-8'), 22.8(C-7, C-7', C-16,C-16'), 14.2(C-17, C-17'). DEPT: Showed the presence of two methyl carbons, twenty methylene carbons and one methine carbon suggesting the molecular weight as 676. MS (rel. Int.): $\mathrm{m} / \mathrm{z}=675\left[\mathrm{M}^{+}-\mathrm{H}\right]$. The structure of compound 1 has been arrived at based on the above spectral information combined with those of compound 2 and compound 3 . The free radical scavenging and anti-tumor potentials of compound 1 were evaluated by 2,2-diphenyl-1-picrylhydrazyl (DPPH) $\operatorname{method}^{[4]}$ and cytotoxic activity by 3-(4,5-Dimethylthiazol-2yl)-2,5-Diphenyltetrazolium Bromide (MTT) assay using Michigan Cancer Foundation-7 (MCF-7) cell $\operatorname{lines}^{[5]}$. These activities were also compared with the parent quinone compound 2 and the dimer, compound 3. Embelin possesses a wide variety of biological activities, the prominent one being its anti-tumour ${ }^{[3]}$ and antioxidant potential ${ }^{[6]}$. The compound's tolerance of toxicity up to the oral dose of $3000 \mathrm{mg} / \mathrm{kg}$ body weight in rats indicated its safety ${ }^{[7]}$. Due of the widespread applications of compound 2, its derivatives have also been screened for a battery of biological activities. In this study, compound 1 , another derivative of compound 2 has been synthesized from the latter (fig. 2) and its structure was confirmed by spectroscopic methods. The free radical scavenging and cytotoxic activities of compound 1 has been carried out in in vitro models (DPPH and MTT assay) and the results are presented in Table 1 and 2 respectively. The studies revealed that compound 1 exhibited a significant radical scavenging activity when compared to standard drug ascorbic acid. Compounds 2 and 3 showed relatively less activities. Quinones are acknowledged as potent antioxidants and reported to possess strong free radical scavenging properties. In the in vitro methods, the DPPH employed has relatively stable nitrogen-centered free radical that can easily accept an electron or hydrogen radical to become a stable diamagnetic molecule. From the data, it might be proposed that compound 1 could able to reduce the stable free radical of DPPH to the yellow-coloured diphenyl picrylhydrazine exhibiting better free radical scavenging activity in comparison with the standard drug ascorbic acid. The structural-activity relationship

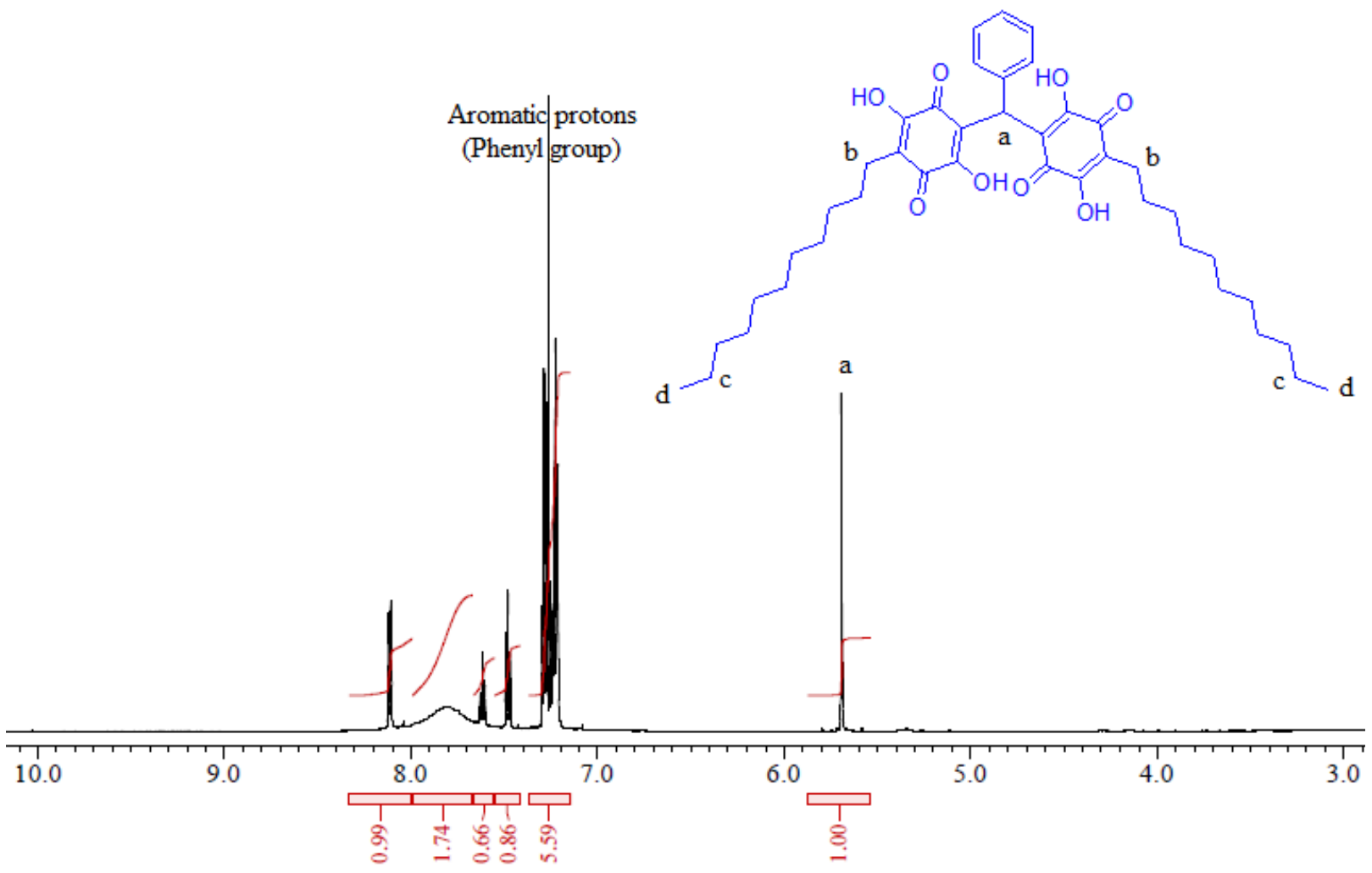

$\mathrm{X}$ : parts per Million : Proton

Fig. 1: ${ }^{1} \mathrm{H}-\mathrm{NMR}$ spectrum of phenylvilangin 


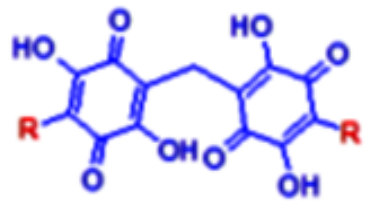

3
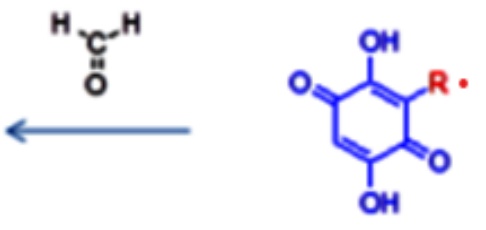

2
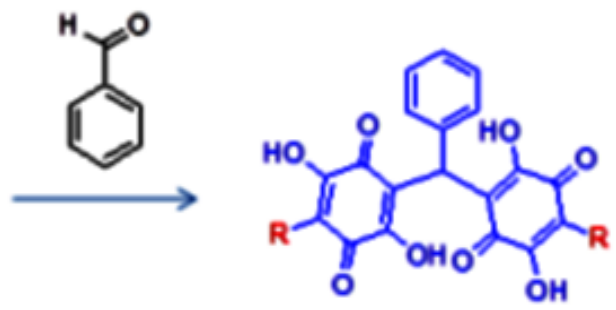

1

$=\left(\mathrm{CH}_{2}\right)_{10} \mathrm{CH}_{3}$

Fig. 2: Synthesis of phenylvilangin (compound 1) and vilangin (compound 3) from embelin (compound 2)

TABLE 1: FREE RADICAL SCAVENGING ACTIVITY OF PHENYLVILANGIN (COMPOUND 1), EMBELIN (COMPOUND 2) AND VILANGIN (COMPOUND 3) BY DPPH METHOD

\begin{tabular}{lcccc}
\hline $\begin{array}{l}\text { Concentration } \\
(\mu \mathrm{g} / \mathrm{mL})\end{array}$ & \multicolumn{4}{c}{ Percentage inhibition of DPPH by tested compounds } \\
\cline { 2 - 5 } & 1 & 2 & 3 & $\begin{array}{c}\text { Standard } \\
\text { (Ascorbic acid) }\end{array}$ \\
40 & $31.77 \pm 0.15$ & $21.33 \pm 0.15$ & $28.12 \pm 0.35$ & $49.89 \pm 0.12$ \\
60 & $39.05 \pm 0.54$ & $32.19 \pm 0.17$ & $36.89 \pm 0.65$ & $51.66 \pm 0.25$ \\
80 & $46.18 \pm 0.29$ & $41.18 \pm 0.36$ & $48.01 \pm 0.31$ & $57.64 \pm 0.11$ \\
100 & $52.15 \pm 0.13$ & $48.15 \pm 0.13$ & $56.32 \pm 0.43$ & $63.09 \pm 0.31$ \\
\hline
\end{tabular}

TABLE 2: CYTOTOXIC ACTIVITY OF PHENYLVILANGIN (COMPOUND 1), EMBELIN (COMPOUND 2) and VILANGIN (COMPOUND 3) BY MTT ASSAY

\begin{tabular}{lcccccccccc}
\hline \multicolumn{10}{c}{ Viability \% } \\
\hline Compound & \multicolumn{10}{c}{ Sample concentration $(\mu \mathrm{g} / \mathrm{mL})$} \\
& $\mathbf{1 0 0 0}$ & $\mathbf{5 0 0}$ & $\mathbf{2 5 0}$ & $\mathbf{1 2 5}$ & $\mathbf{6 2 . 5}$ & $\mathbf{3 1 . 2}$ & $\mathbf{1 5 . 6}$ & $\mathbf{7 . 8}$ & Cell & $\mathrm{IC}_{50}(\boldsymbol{\mu g} / \mathrm{mL})$ \\
& 13.17 & 20.34 & 29.12 & 37.11 & 49.53 & 56.43 & 67.56 & 74.92 & 100 & 56 \\
1 & 16.24 & 21.11 & 33.42 & 49.01 & 58.21 & 72.67 & 81.62 & 90.98 & 100 & 119 \\
2 & 19.19 & 28.16 & 40.5 & 51.16 & 59.1 & 69.56 & 78.21 & 92.53 & 100 & 139 \\
3 & 18
\end{tabular}

study revealed that the antioxidant activity of compound 1 could be attributed to the electron donating nature of the $-\mathrm{OH}$ on hydroquinone scaffold followed by reduction of free radical DPPH and prevention of cell damage. The cytotoxic study data revealed that compound 1 had higher activity towards cancerous MCF-7 cell line at low concentration with $\mathrm{IC}_{50}$ value $56 \mu \mathrm{g} / \mathrm{ml}$. This might be attributed to the sensitivity of cancer cell over compound 1 as well as the difference in membrane structure and protein composition ${ }^{[8]}$. Further the significant antitumor activity of compound 1 may also be attributed to its molecular size, hydrophobic nature of undecayl carbon chain and steric hindrance which might have improved its cellular permeability and restriction towards cancer progression ${ }^{[9]}$.

\section{Acknowledgements:}

The authors thank the management of Saveetha Institute of Medical and Technical Sciences (SIMATS), Chennai for facilities and encouragement. They also express their thanks to Sophisticated Analytical Instrumentation Facility, I.I.T.Bombay, Mumbai for recording spectral data of the compounds.

\section{Conflict of interests:}

The authors declared no conflict of interest.

\section{REFERENCES}

1. Poojari R. Embelin-a drug of antiquity: shifting the paradigm towards modern medicine. Expert Opin Investig Drugs 2014;23(3):427-44. 
2. Balachandran C, Duraipandiyan V, Balakrishna K, Sundaram RL, Vijayakumar A, Ignacimuthu S, et al. Synthesis and medicinal properties of plant-derived vilangin. Environ Chem Lett 2013;11(3):303-8.

3. Chitra M, Sukumar E, Suja V, Devi S. Antitumor, antiinflammatory and analgesic property of embelin, a plant product. Chemother 1994;40(2):109-13.

4. Wang $\mathrm{X}, \mathrm{Li} \mathrm{X}$, Chen D. Evaluation of antioxidant activity of isoferulic acid in vitro. Nat Prod Commun 2011;6(9):1934578X1100600919.

5. Mosmann T. Rapid colorimetric assay for cellular growth and survival: application to proliferation and cytotoxicity assays. J Immunol Methods 1983;659(1-2):55-63.
6. Gupta R, Sharma AK, Sharma MC, Gupta RS. Antioxidant activity and protection of pancreatic $\beta$-cells by embelin in streptozotocin-induced diabetes. J Diabetes 2012;4(3):248-56.

7. Rathinam K, Santhakumari G, Ramiah N. Studies on the antifertility activity of embelin. J Res Ind Med 1976;11:84-90.

8. Perumalsamy H, Sankarapandian K, Kandaswamy N, Balusamy SR, Periyathambi D, Raveendiran N. Cellular effect of styrene substituted biscoumarin caused cellular apoptosis and cell cycle arrest in human breast cancer cells. Int J Biochem Cell Biol 2017;92:104-14.

9. Narendran K, Nanthini R. In vitro biocompatibility evaluation of biscoumarin based random copolyesters. New J Chem 2015;39(6):4948-56. 